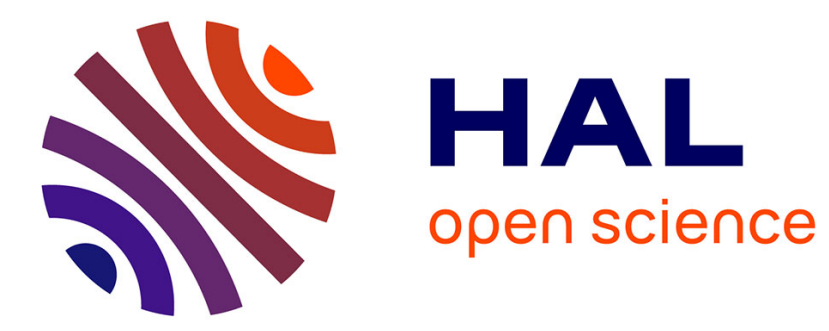

\title{
Phylogenetic relationships within Aglaopheniidae (Cnidaria, Hydrozoa) reveal unexpected generic diversity
}

Bautisse Postaire, Hélène Magalon, Chloé A.-F. Annie-France Bourmaud, Nicole Gravier-Bonnet, J. Henrich Bruggemann

\section{To cite this version:}

Bautisse Postaire, Hélène Magalon, Chloé A.-F. Annie-France Bourmaud, Nicole Gravier-Bonnet, J. Henrich Bruggemann. Phylogenetic relationships within Aglaopheniidae (Cnidaria, Hydrozoa) reveal unexpected generic diversity. Zoologica Scripta, 2015, 45 (1), pp.103-114. 10.1111/zsc.12135 . hal01253738

\section{HAL Id: hal-01253738 \\ https://hal.science/hal-01253738}

Submitted on 26 Apr 2016

HAL is a multi-disciplinary open access archive for the deposit and dissemination of scientific research documents, whether they are published or not. The documents may come from teaching and research institutions in France or abroad, or from public or private research centers.
L'archive ouverte pluridisciplinaire HAL, est destinée au dépôt et à la diffusion de documents scientifiques de niveau recherche, publiés ou non, émanant des établissements d'enseignement et de recherche français ou étrangers, des laboratoires publics ou privés. 


\title{
Phylogenetic relationships within Aglaopheniidae (Cnidaria, Hydrozoa) reveal unexpected generic diversity
}

\author{
Bautisse Postaire, Helene Magalon, Chloe A.-F. Bourmaud, Nicole Gravier-Bonnet \& \\ J. Henrich BruggemanN
}

\begin{abstract}
Postaire, B., Magalon, H., Bourmaud, C.A.-F., Gravier-Bonnet, N., Bruggemann, J.H. (2016). Phylogenetic relationships within Aglaopheniidae (Cnidaria, Hydrozoa) reveal unexpected generic diversity. - Zoologica Scripta, 45, 103-114.

Morphology can be misleading in the representation of phylogenetic relationships, especially in simple organisms like cnidarians and particularly in hydrozoans. These suspension feeders are widely distributed in many marine ecosystems, and the family Aglaopheniidae Marktanner-Turneretscher, 1890 is among the most diverse and visible, especially on tropical coral reefs. The taxonomy of this family is based on morphological characters with emphasis on reproductive structures for the identification of genera. This study is the most comprehensive molecular phylogeny of the Aglaopheniidae to date, including six genera and 38 species, of which 13 were investigated for the first time and sampled on tropical coral reefs throughout the Indo-Pacific region. For newly sampled individuals, we sequenced the $16 \mathrm{~S}$ rRNA, the nuclear locus comprising the complete ITS1-5.8S rRNA gene-ITS2 and the first intron of the calmodulin nuclear gene. Phylogenetic analyses of the data revealed and confirmed a general polyphyly, or doubtful monophyly, of all sampled genera in tropical regions based on both the mitochondrial and nuclear markers. Our results revealed that several morphological characters used today are unsuited to resolve phylogenetic relationships between species and genera, as well as the high phyletic diversity within this family. Future revision of the classification of this family will require extensive geographic sampling and the use of an integrative approach.

Corresponding author: Bautisse Postaire, Laboratoire d'Excellence CORAIL, Université de La Réunion UMR ENTROPIE 9220, CS 92003, 97744 Saint Denis CEDEX 9, France. E-mail: bautisse.postaire@univ-reunion.fr

Bautisse Postaire, Helene Magalon,, Chloe A.-F. Bourmaud,, Nicole Gravier-Bonnet, and 7. Henrich Bruggemann, Laboratoire d'Excellence CORAIL, Université de La Réunion UMR ENTROPIE 9220, CS 92003, 97744 Saint Denis CEDEX 9, France.E-mails: bautisse.postaire@univ-reunion.fr, belene.

magalon@univ-reunion.fr, chloe.bourmaud@univ-reunion.fr, nicole.gravier-bonnet@univ-reunion.fr, benrich.bruggemann@univ-reunion.fr
\end{abstract}

\section{Introduction}

Prerequisites for conservation planning are inventories of species, which are often recognised and described using morphological clues (The House of Lords 2003; The Royal Society 2003; Mace 2004). However, taxa identification using morphological criteria may be challenging, especially in simple organisms that present few discriminant synapomorphies and high phenotypic plasticity, such as cnidarians [see Daly et al. (2007) for a review]. Moreover, molecular phylogenies have shown that a morphological approach is not always representative of the diversity and phylogenetic relationships between species, genera, families and even higher levels in Cnidaria (e.g. Bridge et al. 1992; Chen et al. 1995; Berntson 1999; Daly et al. 2003; Benzoni et al. 2010; Budd et al. 2010; Brugler et al. 2013; Arrigoni et al. 2014; Kitano et al. 2014). This general problem in Cnidaria also pertains to Hydrozoa, (e.g. Bridge et al. 1992; Schuchert 1993; Bouillon \& Boero 2000; Marques \& Collins 2004; Leclère et al. 2009; Peña Cantero et al. 2009; Cartwright \& Nawrocki 2010; Lindner et al. 2011), highlighting the need for a systematic revision of this cnidarian class. 
The Aglaopheniidae (Marktanner-Turneretscher, 1890) hydrozoan family is one of the largest, comprising eight genera and over 250 described species (Bouillon et al. 2006). Genera are defined by reproductive apparatus (gonosome) morphology in addition to the general morphology of the rest of the colony (trophosome) (Allman 1883; Nutting 1900; Millard 1975; Calder 1997; Bouillon et al. 2006). However, gonosome morphology and the life cycle of hydrozoan species were recently shown to present several cases of plesiomorphy and convergent evolution (Leclère et al. 2007, 2009). Therefore, its use as criteria for identifying Aglaopheniidae genera is now arguable. A recently published molecular phylogeny of this family (Moura et al. 2012), based on 25 putative species belonging to six genera, partially supported the monophyly of some genera but rejected the existing classification based on gonosome morphology. The study by Moura et al. (2012) included a large number of species; however, most samples were collected from temperate regions in the Atlantic Ocean and Mediterranean Sea, implying that a part of the phyletic diversity within Aglaopheniidae might have been missed. Nutting (1900) already noted that the Aglaopheniidae diversity (family Statoplea according to the author) was particularly high in the tropical Atlantic Ocean (West Indies). Since then, an important volume of literature has confirmed the diversity of Aglaopheniidae in tropical seas, especially on coral reefs (see Vervoort 1967; Calder 1997; Schuchert 2003; Gravier-Bonnet \& Bourmaud 2006a,b, 2012; Di Camillo et al. 2008). Consequently, sampling the tropical Indo-Pacific region represents a valuable enrichment of the data set, improving the assessment of the phyletic diversity of this family.

The $16 \mathrm{~S}$ mitochondrial rRNA marker is widely used in cnidarian phylogenetic and phylogeographic studies (e.g. Bridge et al. 1995; Romano \& Palumbi 1997; Collins et al. 2005; Peña Cantero et al. 2009; Cartwright \& Nawrocki 2010; Addamo et al. 2012; Miglietta \& Cunningham 2012; Hibino et al. 2014) and has shown a certain consistency with nuclear markers (Miranda et al. 2010; Schuchert 2014). However, using a single mitochondrial marker is not appropriate to study ancient phylogenetic relationships as it may present incomplete lineage sorting and introgression. Additional markers, each having a unique phylogenetic history and mutation rate, should be used to improve the resolution and the reliability of phylogenetic reconstructions. The internal transcribed spacers of the nuclear rDNA (ITS: including the entire ITS1, 5.8S gene and ITS2) present interesting characteristics for reconstructing phylogenetic relationships: biparental inheritance, easy amplification and universality (Barco et al. 2010; Imazu et al. 2014; Kitano et al. 2014). However, due to its high variability, ITS is more appropriate for the study of interspecific phylogenetic relationships (see Schuchert 2014). For higher taxonomic ranks, the calmodulin, a ubiquitously conserved gene, has proved to be a reliable marker (Baba et al. 1984) used for reconstructing cnidarian phylogenies (Lindner et al. 2008).

This study aimed to improve knowledge on Aglaopheniidae phylogeny, primarily by enlarging the geographic coverage of included taxa, focussing sampling efforts on tropical coral reefs in the south-west Indian Ocean and the south-west Pacific - two marine biodiversity hotspots (Roberts et al. 2002) - as well as in the central Pacific. Using a multilocus approach, we provide a new insight into the phylogenetic relationships within this family and discuss current taxonomy and its validity.

\section{Material and methods Sampling}

Samples were collected manually between 2007 and 2014 from shallow coral reef habitats $(0-40 \mathrm{~m}$ depth $)$ at six localities in the south-west Indian Ocean (SWIO, 15 sites per locality), one locality in the south-west Pacific (New Caledonia, 18 sites) and one in the central Pacific (Moorea, French Polynesia, three sites) (Fig. 1, Table S1). Each sampling site was prospected for Aglaopheniidae species using SCUBA or by snorkelling. To facilitate taxonomic identification, larger colonies (i.e. $3-40 \mathrm{~cm}$ high) were preferentially collected with visible gonosomes. Parts of colonies, referred to as individuals, were collected several metres apart to reduce the probability of sampling the same colony (genet). Samples were identified based on morphological characters by CAFB, NG-B and BP, using taxonomic literature (see references listed in Gravier-Bonnet \& Bourmaud 2006a,b, 2012). For species and genera lists the 'Hydrozoa Handbook' (Bouillon et al. 2006) was used. A minimum of three individuals per species were collected and sequenced. Specimens were fixed and preserved in $90 \%$ ethanol for DNA extraction. Whenever possible, a voucher of each sequenced specimen was also preserved in a $3 \%$ formalin solution in sea water. Samples are currently stored in the laboratory at the University of Reunion Island and are available on request.

\section{Sequencing}

Prior to DNA extraction, all gonophores were removed from the colonies. DNA was extracted from one or two hydrocauli per colony using the DNeasy Blood \& Tissue Kit (Qiagen, Hilden, Germany) following the manufacturer's protocol. Extraction quality was assessed on a $0.8 \%$ agarose gel stained with GelRed Nucleic Acid Stain, 

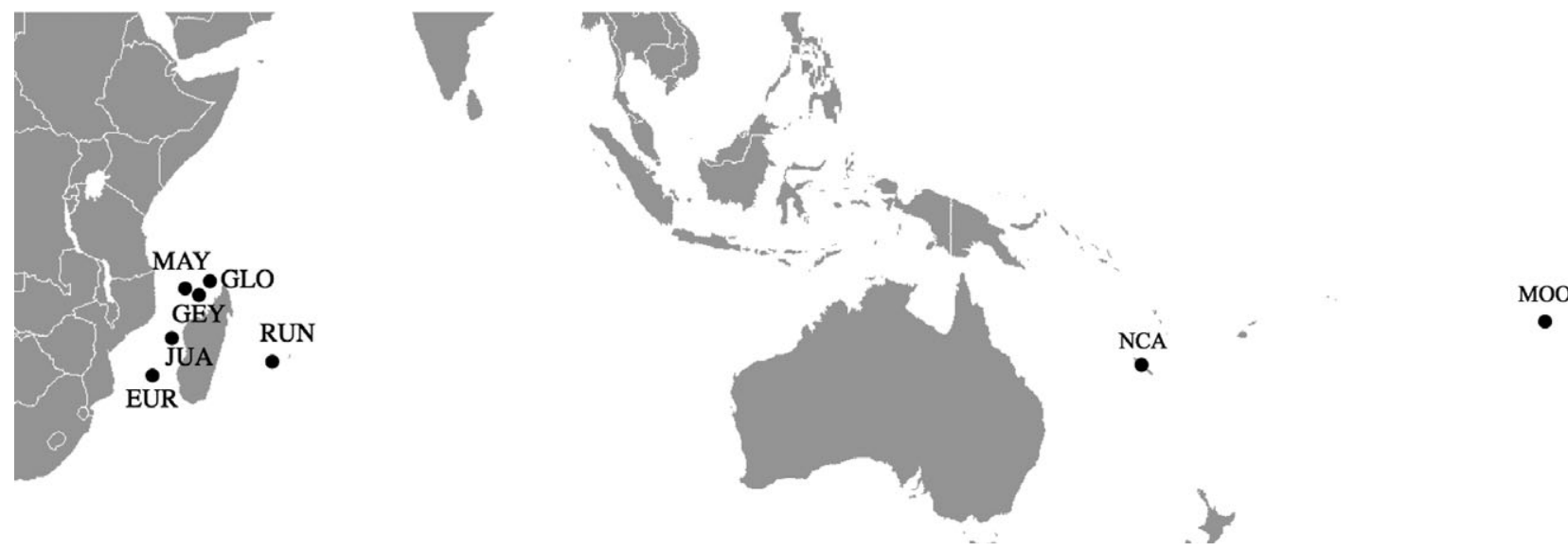

Fig. 1 Sampling locations in the south-west Indian Ocean and west Pacific and central Pacific included in this study. EUR, Europa Island; GEY, Geyser bank; GLO, Glorieuses Islands; JUA, Juan de Nova Island; MAY, Mayotte; NCA, New Caledonia; RUN, Reunion Island; MOO, Moorea.

10000 in DMSO (Gentaur, Kampenhout, Belgium). Each PCR was conducted in a total volume of $30 \mu \mathrm{L}: 15 \mu \mathrm{L}$ $(0.625 \mathrm{U})$ of AmpliTaq mix (Applied Biosystems, Waltham, MA, USA), $0.5 \mu \mathrm{L}$ of each primer $(10 \mu \mathrm{M})$ and $4 \mu \mathrm{L}$ of template DNA (final concentration: $1.6 \mathrm{ng} / \mu \mathrm{L}$ ) and completed with $10 \mu \mathrm{L}$ of ultra-pure water. We amplified and sequenced a fragment of the 16S rRNA (16S) mitochondrial gene with primers SHA (5'-ACG GAA TGA ACT CAA ATC ATG T- $\left.3^{\prime}\right)$ and SHB (5'-TCG ACT GTT TAC CAA AAA CAT A-3') (Cunningham \& Buss 1993) and two nuclear regions: (i) a fragment of the calmodulin (CAM) gene with primers CAMF1 (5'-GAT CAA YTR CAN GAR GAA CAA ATT GC- $3^{\prime}$ ) and CAMR1 (5'-CCA TCN CCA TCR ATA TCA GC-3') (Lindner et al. 2008), and (ii) the complete internal transcribed spacer 1, 5.8S rDNA and internal transcribed spacer two region of the ribosomal DNA (ITS) with partial $18 \mathrm{~S}$ and $28 \mathrm{~S}$ ribosomal genes flanking the two ITS, respectively, upstream and downstream with primers ITSF (5'-CAC CGC CCG TCG CTA C TA CCG ATT GAA TGG-3') and ITSR (5'-CGC TTC ACT CGC CGT TAC TAG GGG AAT CC-3') (Martínez et al. 2010). The PCR conditions for $16 \mathrm{~S}$ and CAM markers were as follows: $\left(5 \mathrm{~min}\right.$ at $\left.95{ }^{\circ} \mathrm{C}\right),\left(30 \mathrm{~s}\right.$ at $94{ }^{\circ} \mathrm{C} ; 30 \mathrm{~s}$ at $46^{\circ} \mathrm{C}$; $1 \mathrm{~min}$ at $\left.72{ }^{\circ} \mathrm{C}\right) \times 5,\left(30 \mathrm{~s}\right.$ at $94^{\circ} \mathrm{C} ; 30 \mathrm{~s}$ at $51^{\circ} \mathrm{C} ; 1 \mathrm{~min}$ at $\left.72{ }^{\circ} \mathrm{C}\right) \times 30$, and $\left(5 \mathrm{~min}\right.$ at $\left.72{ }^{\circ} \mathrm{C}\right)$. The PCR conditions for the ITS marker were as follows: $\left(5 \mathrm{~min}\right.$ at $95^{\circ} \mathrm{C}$ ), $\left(30 \mathrm{~s}\right.$ at $94{ }^{\circ} \mathrm{C} ; 30 \mathrm{~s}$ at $55^{\circ} \mathrm{C} ; 1 \mathrm{~min}$ at $72^{\circ} \mathrm{C}$ ) x 35 and $\left(5 \mathrm{~min}\right.$ at $\left.72{ }^{\circ} \mathrm{C}\right)$. PCR products were visualised on a $1 \%$ agarose gel stained with GelRed Nucleic Acid Stain, 10000 in DMSO (Gentaur, Kampenhout, Belgium). PCR products were sequenced in both directions by Genoscope (CEA Evry, France) and by Genoscreen (Lille, France) on capillary sequencer ABI3730XL.

\section{Tree reconstruction}

Sequences were checked and edited using Geneious 6.0 (http://www.geneious.com; Kearse et al. 2012) and deposited on GenBank (Table S2). Additional mitochondrial sequences previously published were retrieved from GenBank (Table S2). Sequences were aligned using Muscle algorithm (Geneious plug-in; Edgar 2004) and trimmed to the shortest sequence. To assess the general position of newly sampled species within the Aglaopheniidae phylogeny, 16S marker was analysed first, separately from the others. After checking for incongruences, phylogenetic relationships among the coral reef Aglaopheniidae species were analysed using the concatenated data set (i.e. mitochondrial and nuclear markers). We used Jmodeltest (stand-alone version; Darriba et al. 2012) to determine the best probabilistic model of sequence evolution based on AIC (16S: GTR+I+G; CAM: TPM2uf $+\mathrm{I}+\mathrm{G} ; \quad$ ITS: TIM1 $+\mathrm{I}+\mathrm{G})$. We performed maximum likelihood (ML) using PhyML (Geneious plug-in; Guindon et al. 2010) and Bayesian inferences (BI) analyses using MrBayes 3.2 (three independent runs of: $100.10^{6}$ generations, eight chains, temperature to $0.2,10 \%$ burnin length, sampling every $1.10^{5}$ generations (Geneious plug-in; Ronquist et al. 2012). Nodes can be considered robust if their posterior probability (PP) is equal or higher to 0.95 when considering Bayesian reconstruction and when their bootstrap (BS) values are superior to $75 \%$ considering $M L$ reconstruction (Erixon et al. 2003). These definitions were used thereafter. We used the same outgroups as Moura et al. (2012) for the 16S tree reconstruction, that is Schizotricha turqueti (Billard, 1906) and Schizotricha nana Peña Cantero et al. 1996 . As no sequences of ITS and calmodulin were available for these species, sequences from a Campanulariidae species [Clytia gracilis (Fraser, 1938)] were used for 
tree reconstructions, for the nuclear markers and for the concatenated data set.

\section{Results and discussion}

Our research represents the most comprehensive phylogenetic study of the family Aglaopheniidae to date, in terms of the number of taxa, genes included and geographic coverage, comprising sites from the Atlantic, south-west Indian Ocean and the south-west to central Pacific. For the 16S, a total of 238 sequences were analysed, comprising six genera and 38 species (Table S2); after alignment, 511 sites were retained of which 274 $(53.6 \%)$ were parsimony-informative (i.e. at least two different bases for a given site, each represented at least twice). The calmodulin gene data set included 143 sequences of 330 sites, with 95 parsimony-informative sites (28.8\%). For ITS, 143 sequences of 937 sites were obtained, with 432 parsimony-informative sites (46.1\%). The results of $\mathrm{BI}$ and $\mathrm{ML}$ were almost identical, but BI analyses provided generally stronger nodal supports than ML. Phylogenies of the mitochondrial and nuclear markers (16S, calmodulin, ITS; Figs S1-S3, respectively) yielded similar topologies for the coral reef species studied, except for the position of Macrorbynchia sp. n. (Figs $\mathrm{S} 1-\mathrm{S} 3$ ). This species, primarily distinguished using morphological characters, formed a robust clade with other Macrorbynchia (Kirchenpauer, 1872) species when considering the nuclear markers separately (Figs S2 and S3), but not when considering only the mitochondrial marker (Fig. 2; Fig. S1). The marker $16 \mathrm{~S}$ has been shown useful for barcoding hydrozoan species (Leclère et al. 2007, 2009; Moura et al. 2008, 2011, 2012; Zheng et al. 2014). However, several studies revealed its possible higher mutation rate in Aglaopheniidae compared to other hydrozoan families (Leclère et al. 2007; Moura et al. 2008; Peña Cantero et al. 2009). This characteristic might impede the reconstruction of intergeneric phylogenetic relationships in this family; to account for this possibility, we also used both slow (calmodulin) and fast (ITS) evolving nuclear markers (for tropical species only). The comparison of the different phylogenetic trees reconstructed using $16 \mathrm{~S}$, calmodulin or ITS (Figs S1-S3, respectively) revealed that none gave a good representation of ancient relationships within this family and that all genera are polyphyletic (except Macrorbynchia when using nuclear markers) (Figs S1-S3). Thus the high polyphyly of Aglaopheniidae genera might not be a simple artefact from the mitochondrial marker but highlight of the fact that we do not know to what extent evolutionary divergence is reflected in Aglaopheniidae morphology. Considering these results, and as the $16 \mathrm{~S}$ marker might in addition not be representative of phylogenetic relationships due to its maternal inheritance (Hurst \& Jiggins 2005), we analysed the three markers concomitantly by concatenating them for the newly sequenced species.

\section{Groups of taxa in Aglaopheniidae}

Nodes discussed below (mitochondrial marker and/or concatenated data set) are supported by both Bayesian [posterior probability (PP)] and maximum likelihood [bootstrap (BS)] reconstructions and are considered robust (i.e. $\mathrm{PP}>0.95$ and $\mathrm{BS}>75)$.

The phylogeny based on $16 \mathrm{~S}$, including all available sequences and newly sequenced species, is presented in Fig. 2. We identified three divergent and strongly supported clades within the family Aglaopheniidae: first, the genus Streptocaulus (Allman, 1883) at the base of the phylogeny (Fig. 2: A; PP = 1, BS = 100); second, the genus Gymnangium (Hincks, 1874) excluding G. eximium (Allman, 1874) and G. gracilicaule (Jäderholm, 1903) (Fig. 2: B; $\mathrm{PP}=1, \quad \mathrm{BS}=100) ;$ and third, the genera Aglaophenia Lamouroux, 1812; Cladocarpus (Allman, 1874), Lytocarpia (Kirchenpauer, 1872) and Macrorbynchia, and the two species G. eximium and G. gracilicaule (Fig. 2: C-N; $\mathrm{PP}=0.98, \quad \mathrm{BS}=79)$. The newly obtained sequences improved the resolution of the tree, and the third major clade $(\mathrm{C}-\mathrm{N})$ comprised three subclades: (a) the genus Cladocarpus (Fig. 2: C; $\mathrm{PP}=1, \mathrm{BS}=98$ ), (b) the genus Macrorbynchia and the species G. eximium, G. gracilicaule and Lytocarpia nigra (Nutting, 1905) gathered in a partially supported clade (Fig. 2: F-H; PP $=0.99$, BS < 75), and (c) several Lytocarpia and Aglaophenia species (Fig. 2: D, E, I$\mathrm{N})$. The use of nuclear markers confirmed the major clade composed of subclades F to $\mathrm{H}$ (Fig. 3 ; $\mathrm{PP}=0.99, \mathrm{BS}=97$ ) and the monophyly of L. brevirostris (Fig. 3: J; PP $=1$, $\mathrm{BS}=100)$.

In the light of these new phylogenies, the genus Gymnangium is clearly polyphyletic, either when the $16 \mathrm{~S}$ is analysed alone (Fig. 2: B and H), in agreement with previous studies (Moura et al. 2008, 2012; Leclère et al. 2009), or when the nuclear markers are included (Fig. 3: B and H). Likewise, the genera Aglaophenia and Lytocarpia are polyphyletic groups for both mitochondrial and nuclear markers, results congruent with those of Moura et al. (2012). In contrast, the Macrorbynchia species are closely related when excluding Macrorbynchia sp. n. based on the 16S (Fig. 2: G), but nuclear markers reveal the monophyletic status of this genus, including Macrorbynchia sp. n (Fig. 3: G). Finally, the species of the genera Cladocarpus (Fig. 2: C) and Streptocaulus (Fig. 2: A), inhabiting deep waters, were not sampled in the present study: their monophyletic status can therefore neither be confirmed nor discussed. 


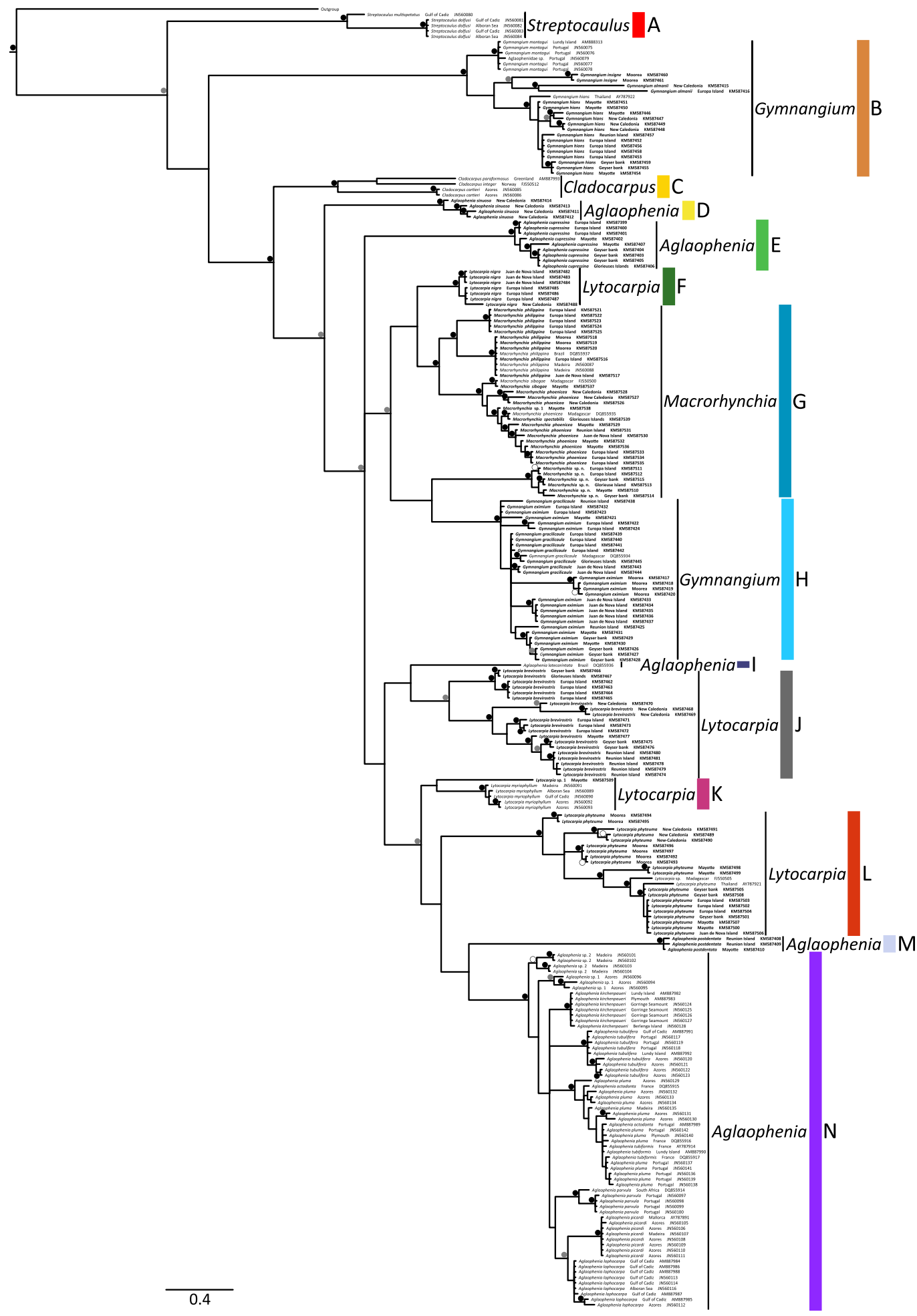

Fig. 2 Molecular phylogeny of Aglaopheniidae species generated by PhyML from $16 \mathrm{~S}$ gene sequences. Black thick vertical lines indicate positions of genera. Support values of nodes are indicated: black dots indicate PP superior to 0.95 and $\mathrm{ML}$ bootstrap values superior to $75 \%$; grey dots indicate PP superior to 0.95 and bootstrap values of maximum likelihood inferior to $75 \%$; white dots indicate PP inferior to 0.95 and bootstrap values of maximum likelihood superior to $75 \%$. Nodes with PP inferior to 0.95 and bootstrap values of maximum likelihood inferior to $75 \%$ are not indicated. Distances are expressed in number of substitution per site. Uppercase letters and colour codes delineate lineages referred to Table 1 and congruent with Fig. 3. 


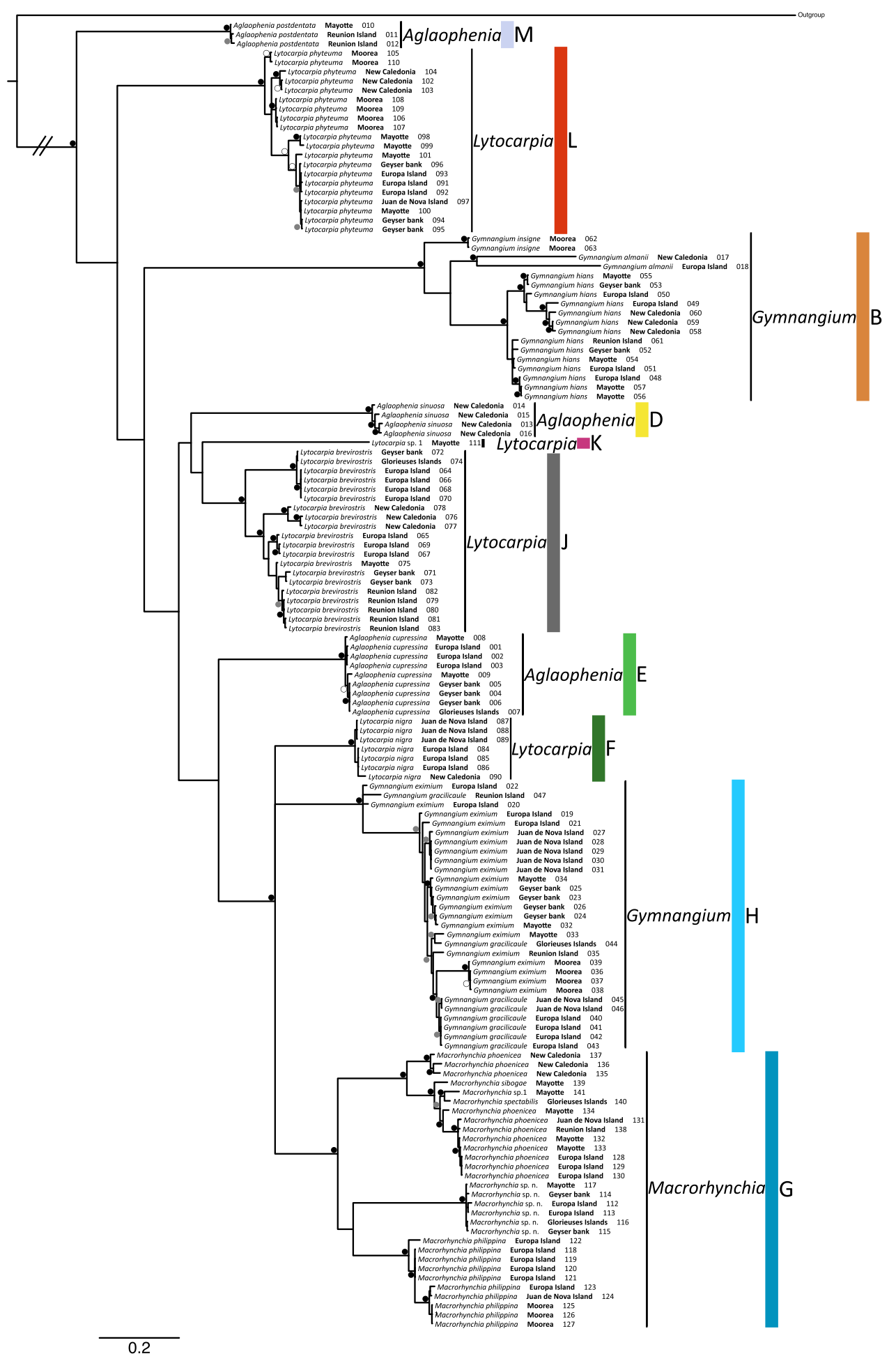

Fig. 3 Molecular phylogeny of 18 tropical Aglaopheniidae species generated by PhyML from 16S, ITS and calmodulin sequences. Black thick vertical lines indicate positions of genera. Support values of nodes are indicated: black dots indicate PP superior to 0.95 and bootstrap values of maximum likelihood superior to $75 \%$; grey dots indicate PP superior to 0.95 and bootstrap values of maximum likelihood inferior to $75 \%$; white dots indicate PP inferior to 0.95 and bootstrap values of maximum likelihood superior to $75 \%$. Nodes with PP inferior to 0.95 and bootstrap values of maximum likelihood inferior to $75 \%$ are not indicated. Distances are expressed in number of substitution per site. Uppercase letters and colour codes delineate lineages referred to Table 1 and congruent with Fig. 2. 


\section{Phyletic richness of Aglaopheniidae genera}

Moura et al. (2012) found the genus Aglaophenia to be polyphyletic due to the absence of grouping of $A$. latecarinata (Allman, 1877) with other Aglaophenia species. The inclusion of three newly sampled species of this genus (A. cupressina Lamouroux, 1816; A. postdentata Billard, 1913 and A. sinuosa Bale, 1888) supports this result. Aglaophenia cupressina (E) and A. sinuosa (D) are part of a large clade that includes the genera Lytocarpia, Aglaophenia and Macrorbynchia and two Gymnangium species, but are divergent among each other and separated from other Aglaophenia (Figs 2 and 3). With 75 valid species, the genus Aglaophenia is the most diverse of the family (Bouillon $e t$ al. 2006). Our results validate its polyphyletic status and suggest that it is composed of several divergent monophyletic taxa: based on our data, the genus Aglaophenia is composed by at least five divergent lineages (Figs 2 and 3: $\mathrm{D}, \mathrm{E}, \mathrm{I}, \mathrm{M}, \mathrm{N}$; Table 1). These results question the validity of this genus and the reliability of the morphological characters used to define it, that is gonothecae protected by accessory structures, called corbulae, lacking hydrothecae at the base of the ribs (Millard 1975; Schuchert 2003; Bouillon et al. 2006). From its creation by Lamouroux (1812), the genus Aglaophenia has presented a very complex history, as summarised by Calder (1997). Today, with a more comprehensive sampling as a prerequisite, the genus Aglaophenia should attract attention for a taxonomic revision, which might lead to the denomination of new clades in the Aglaopheniidae family. Interestingly, Aglaophenia

Table 1 Grouping at genus level of the 38 species analysed based on molecular data in this study

\begin{tabular}{lll}
\hline Clade & Genera & Species \\
\hline A & Streptocaulus* & Streptocaulus multiseptatus, S. dolfusi \\
B & Gymnangium & G. montagui, G. allmani, G. hians, G. insigne \\
C & Cladocarpus* & Cladocarpus cartieri, C. integer, C. paraformosus \\
D & Aglaophenia? & Aglaophenia sinuosa \\
E & Aglaophenia? & Aglaophenia cupressina \\
F & Lytocarpia? & Lytocarpia nigra \\
G & Macrorhynchia* & Macrorhynchia phoenicea, M. philippina, M. sibogae, \\
& & M. spectabilis, M sp. n. \\
H & Gymnangium? & Gymnangium eximium, G. gracilicaule \\
I & Aglaophenia? & Aglaophenia latecarinata \\
J & Lytocarpia? & Lytocarpia brevirostris \\
K & Lytocarpia & Lytocarpia myriophyllum, L. sp. 1 \\
L & Lytocarpia? & Lytocarpia phyteuma \\
M & Aglaophenia? & Aglaophenia postdentata \\
N & Aglaophenia & Aglaophenia pluma, A. kirchenpaueri, A. lophocarpa, \\
& & A. octodonta, A. parvula, A. picardi, A. sp. 1, \\
& & A. sp. 2, A. tubiformis, A. tubulifera
\end{tabular}

Type species are in bold. Asterisks indicate clades where the type species of the corresponding genus was not sequenced; question marks indicate that the type species of the genus is not in the corresponding clade. species from the temperate Atlantic Ocean and Mediterranean Sea (Fig. 2: N) form a robust clade, which contains the type species (Table 1, A. pluma (Linnaeus, 1758). This clade $\mathrm{N}$ is composed of 10 species with low interspecific genetic divergences (Moura et al. 2012) and strong morphologic similarities (P. Schuchert, pers. com.).

The addition of new species of Lytocarpia to the phylogeny also highlights the polyphyly of this taxon, consistent with the results of Moura et al. (2012). The species Lytocarpia brevirostris (Busk, 1852) (J), L. myriophyllum (Linnaeus, 1758) (K) and L. phyteuma (Kirchenpauer, 1876) (L) do not form a clade but seem related to Aglaophenia species from the Atlantic and the Mediterranean Sea (Fig. 2: $\mathrm{N}$ ) and A. postdentata (Fig. 2: M), whereas L. nigra (F) is related to Macrorbynchia (G), Gymnangium eximium and $G$. gracilicaule $(\mathrm{H})$. These results question the validity of the diagnostic character for distinguishing the genera Lytocarpia and Aglaophenia, that is the presence/absence of an hydrothecae at the basis of each corbula rib, respectively (Millard 1975). As previously shown by Moura et al. (2012), our results also indicate that the general classification of the Aglaopheniidae based on the morphological characters of the gonosome is not concordant with the phylogeny of the family. Furthermore, species of Lytocarpia belong to two of the major subclades of Aglaopheniidae (Fig. 2: F-H, I-N), indicating that the general diagnostic character of the genus might represent several cases of homoplasy. Indeed, the genus is composed of four divergent lineages, questioning again its general validity (Table 1). However, with only five of the 36 currently recognised species included in this study (Bouillon et al. 2006) and even if the type species is included (Table 1), our sampling of this genus remains limited and a taxonomically more inclusive analysis is needed before considering revising this genus.

Moura et al. (2012) could not conclude on the monophyly of Macrorbynchia as our results based on 16S (Fig. 2: $\mathrm{G})$. Our results cautiously suggest the monophyletic status of this genus (Fig. 3), keeping in mind the scarce taxon sampling and that the type species is not included (Table 1). Furthermore, the phylogenetic relationships between sampled species are different considering the mitochondrial marker or the concatenated data set. Based on the 16S, Macrorbynchia sp. n. does not seem to be closely related to other Macrorbynchia, while $M$. phoenicea (Busk, 1852), M. spectabilis (Allman, 1883) and M. sibogae (Billard, 1913) form robust clades (Fig. 2: G). The addition of nuclear markers (i) supports the monophyly of the genus, (ii) supports the synonymy of $M$. sibogae and M. phoenicea suggested by Di Camillo et al. (2009), (iii) calls into question the validity of $M$. spectabilis (Fig. 3: G) and (iv) highlights the relatedness of Macrorbynchia sp. n. to 
other Macrorbynchia species (Fig. 3; PP =1, BS =100). Macrorbynchia philippina (Kirchenpauer, 1872), on the other hand, forms a robust clade whatever the molecular marker considered (Figs 2 and 3; Figs S1-S3). Thus, we concur that the genus Macrorbynchia is represented in our phylogeny by at least three species (M. philippina, M. phoenicea and Macrorbynchia sp. n.) with unclear phylogenetic relationships.

The taxon Gymnangium, defined by the absence of protective structures on the gonothecae, is divided into two clades according to the $16 \mathrm{~S}$ : one basal to the Aglaopheniidae, composed of G. hians (Busk, 1852), G. montagui (Billard, 1912) [type species], G. allmani (MarktannerTurneretscher, 1890) and G. insigne (Allman, 1876) (Fig. 2: B) and another composed of G. eximium and G. gracilicaule related to L. nigra and Macrorbynchia spp (Fig. 2: H). Once more, our results highlight that the morphological characters of the gonosome are not synapomorphic in this taxon: the genus Gymnangium is composed of two divergent lineages (Fig. 2, Table 1). These results confirm those from previous studies (Leclère et al. 2007; Moura et al. 2012). Thus, this study poses a straightforward question to taxonomists: What common characters explain the phylogenetic relatedness of Macrorbynchia species to L. nigra and the clade composed of G. eximium and G. gracilicaule, considering that the morphological characters of the gonosome are not valid? It should be noted that approximately one century ago, Stechow (1921) proposed to split Gymnangium into three genera (Gymnangium, Haliaria and Halicetta), based on the trophosome characters (i.e. the whole animal except the temporary reproductive structures). One of our lineages (Figs 2 and 3: H; G. gracilicaule and G. eximium) enters in the genus Halicetta Stechow, 1921, while the second (Figs 2 and 3: B) is still in Gymnangium sensu stricto. Thus, the classification based on the trophosome seems, in this case, to be more representative of the phylogenetic relationships between some Aglaopheniidae clades. Our results highlight the importance to insert new additional descriptive characters in the current taxonomy (gathering morphological, phylogenetic, ecological, metabolomic, proteomic data...). Once performed, it would be interesting to test this approach on the genus Gymnangium by constructing a molecular phylogeny of the whole genus and comparing it to the classification proposed by Stechow (1921), potentially resurrecting several genera.

Morphological characters of the gonosome were used in the most recent attempt to classify the family Aglaopheniidae by Calder (1997) which defined two subfamilies: Gymnangiinae Calder, 1997 and Aglaopheniinae Marktanner-Turneretscher, 1890; with two tribes within the second subfamily (Aglaopheniini Marktanner-Turneretscher, 1890; and Cladocarpiini Calder, 1997). Moura et al. (2012) already highlighted that morphological characters of the gonosome are not linked to genetic lineages, and the present study clearly supports their conclusion. With this classification criteria, three of the six Aglaopheniidae genera studied (Aglaophenia, Gymnangium and Lytocarpia) are composed of several highly divergent lineages, based on mitochondrial and nuclear markers: our results reveal that the phyletic diversity of genera is probably underestimated by over $50 \%$ (Table 1) and confirm the importance of evolutionary convergences in this family, a common feature in cnidarians (Belmonte et al. 1997; Collins 2002; Govindarajan et al. 2006; Leclère et al. 2007, 2009; Sinniger et al. 2008; Cartwright \& Nawrocki 2010; McFadden et al. 2010; Nawrocki et al. 2010; Gittenberger et al. 2011; Hoeksema \& Crowther 2011; Brugler et al. 2013; Kayal et al. 2013; Arrigoni et al. 2014; Kitano et al. 2014). Thus, using morphological characters to classify Aglaopheniidae has led to underestimate the family phyletic diversity by unintentionally overlooking possible morphological convergences and by confounding two different phenomena that do not necessarily occur on the same timescale during speciation: cladogenesis and anagenesis.

\section{Aglaopheniidae species are monophyletic}

It should be noted that almost all studied species form monophyletic groups. In other words, our results reveal that morphological characters, even if not representing phylogenetic relationships among species, are able to identify monophyletic groups.

This pattern is typical for adaptive radiation (i.e. the formation of a high number of species on a small geological timescale). Indeed, such radiations can lead to a loss of phylogenetic signal and thus to unresolved phylogenies above the species level (Givnish \& Sytsma 1997). However, the combination of high divergence among tropical species (compared to Atlantic species) and several resolved ancient nodes (Figs 2 and 3; Fig. S2) suggest that this radiation should be extremely old (assuming no changes in mutation rates of markers across time or taxa). It further implies that multiple evolutionary convergences occurred. However, the lack of fossil records is a huge problem to test this scenario, as we cannot calibrate the trees with a real time-based molecular clock.

A plausible alternative hypothesis is that these tropical Aglaopheniidae species, whose determination depends on morphological characters (i.e. morpho-species), do not represent true species, that is monophyletic independent metapopulations (Barberousse \& Samadi 2010). In other groups of organisms with problematic and complex taxonomy, recent studies using species delimitation methods combining sequences and microsatellite data with morphological and geographic data have identified several 
independent species within morpho-species (Ross et al. 2010; Barley et al. 2013; Payo et al. 2013). Thus, each morpho-species of Aglaopheniidae could represent a complex of true species, like hypothesised for another worldwide hydrozoan morpho-species, Plumularia setacea (Linnaeus, 1758), by Schuchert (2014). Such an analysis of species delimitation should be performed to clarify whether these Aglaopheniidae morpho-species are composed or not of several true species.

\section{Conclusions}

These phylogenies, based on several molecular markers, reveal the high phyletic diversity of the Aglaopheniidae and are one of the necessary steps to reassess the taxonomy of this notable hydrozoan family. Our results deliver an important message: we are able to identify Aglaopheniidae species in general, but we have a poor representation of the diversity and phylogenetic relationships of the genera within this family. An integrative approach (Dayrat 2005) must be used, in addition to a more comprehensive sampling, to improve our knowledge of this family. Such method allowed the proposition of a new classification based on morphological characters representing phylogenetic relationships in the Corynidae (Johnston, 1838), another hydrozoan family with a problematic morphological classification including several poly- and paraphyletic genera (Nawrocki et al. 2010).

\section{Acknowledgements}

We gratefully acknowledge the financial support from the French network Bibliotbèque du Vivant, funded by Centre National de Séquençage (CEA), Centre national de la recherche scientifique (CNRS), the Muséum National d'Histoire Naturelle (MNHN), the Institut national de recherche agronomique (INRA), and from the Laboratoire d'Excellence CORAIL (HYDROSOOI programme). We thank the USR 3278 CRIOBE staff and L. Penin for sampling hydrozoans in Moorea. The first author was financially supported by a Ph.D. contract from the STS Doctoral School of the University of Reunion Island. We thank Reshad JhangeerKhan (Mauritian Wildlife Foundation) for his corrections and proof reading.

\section{References}

Addamo, A. M., Reimer, J. D., Taviani, M., Freiwald, A. \& Machordom, A. (2012). Desmophyllum dianthus (Esper, 1794) in the scleractinian phylogeny and its intraspecific diversity. PLoS ONE, 7, e50215.

Allman, G. J. (1874). On the diagnosis of new genera and species of hydroids. Nature, 11, 179.

Allman, G. J. (1876). Diagnoses of new genera and species of hydroids. Fournal of the Linnean Society of London, Zoology, 12, 251-284.
Allman, G. J. (1877). Report on the Hydroida collected during the exploration of the gulf stream by L F. de Pourtalès, assistant United states Coast survey. Memoirs of the Museum of Comparative Zoology, 5, 1-66.

Allman, G. J. (1883). Report on the Hydroida dredged by H.M.S. Challenger during the years 1873-76. Part I. Plumularidae. Report on the Scientific Results of the Voyage of H.M.S. Challenger. Zoology, 7(20), 1-20.

Arrigoni, R., Terraneo, T. I., Galli, P. \& Benzoni, F. (2014). Lobophylliidae (Cnidaria, Scleractinia) reshuffled: Pervasive non-monophyly at genus level. Molecular Phylogenetics and Evolution, 73, 60-64.

Baba, M. L., Goodman, M., Berger-Cohn, J., Demaille, J. G. \& Matsuda, G. (1984). The early adaptive evolution of calmodulin. Molecular Biology and Evolution, 1, 442-455.

Bale, W. M. (1888). On some new and rare Hydroida in the Australian Museum collection. Proceedings of the Linnean Society of New South Wales, 3, 745-799.

Barberousse, A. \& Samadi, S. (2010). Species from Darwin onward. Integrative Zoology, 5, 187-197.

Barco, A., Claremont, M., Reid, D. G., Houart, R., Bouchet, P., Williams, S. T., Cruaud, C., Couloux, A. \& Oliverio, M. (2010). A molecular phylogenetic framework for the Muricidae, a diverse family of carnivorous gastropods. Molecular Phylogenetics and Evolution, 56, 1025-1039.

Barley, A. J., White, J., Diesmos, A. C. \& Brown, R. M. (2013). The challenge of species delimitation at the extremes: diversification without morphological change in philippine sun skinks. Evolution, 67, 3556-3572.

Belmonte, G., Miglietta, A., Rubino, F. \& Boero, F. (1997). Morphological convergence of resting stages of planktonic organisms: a review. Hydrobiologia, 355, 159-165.

Benzoni, F., Stefani, F., Pichon, M. \& Galli, P. (2010). The name game: morpho-molecular species boundaries in the genus Psammocora (Cnidaria, Scleractinia). Zoological fournal of the Linnean Society, 160, 421-456.

Berntson, E. (1999). Phylogenetic relationships within the Class Anthozoa (Phylum Cnidaria) based on nuclear 18S rDNA sequences. Molecular Phylogenetics and Evolution, 13, 417-433.

Billard, A. (1906). Hydrö̈des. In: Expédition Antarctique Française (1903-1905) commandée par le dr fean Charcot. 20pp. (Eds) Paris: Masson et Cie.

Billard, A. (1912). Hydroïdes de Roscoff. Archives De Zoologie Expérimentale Et Générale, 51, 459-478.

Billard, A. (1913). Les hydroïdes de l'expédition du Siboga, i. Plumulariidae. Résultats De l'Exploration Du Siboga, 7, 1-115.

Bouillon, J. \& Boero, F. (2000). The hydrozoa: a new classification in the light of old knowledge. Thalassia Salentina, 24, 3-45.

Bouillon, J., Gravili, C., Pagès, F., Gili, J.-M. \& Boero, F. (2006). An Introduction to Hydrozoa. In: P. Grandcolas, J.-M. Betsch, P. Bouchet \& C. Erard (Eds) Mémoires du Muséum national d'Histoire naturelle (pp. 1-591), Vol. 194. Paris: Mémoires du Muséum d'Histoire Naturelle.

Bridge, D., Cunningham, C. W., Schierwater, B., DeSalle, R. \& Buss, L. W. (1992). Class-level relationships in the phylum Cnidaria: evidence from mitochondrial genome structure. Proceedings of the National Academy of Sciences, 89, 8750-8753.

Bridge, D., Cunningham, C. W., DeSalle, R. \& Buss, L. W. (1995). Class-level relationships in the phylum Cnidaria: molecu- 
lar and morphological evidence. Molecular Biology and Evolution, 12, 679-689.

Brugler, M. R., Opresko, D. M. \& France, S. C. (2013). The evolutionary history of the order Antipatharia (Cnidaria: Anthozoa: Hexacorallia) as inferred from mitochondrial and nuclear DNA: implications for black coral taxonomy and systematics. Zoological fournal of the Linnean Society, 169, 312-361.

Budd, A. F., Romano, S. L., Smith, N. D. \& Barbeitos, M. S. (2010). Rethinking the phylogeny of scleractinian corals: a review of morphological and molecular data. Integrative and Comparative Biology, 50, 411-427.

Busk, G. (1852). An account of the Polyzoa and sertularian zoophytes collected in the voyage of the "rattlesnake" on the coast of Australia and the Louisiade Archipelago. In J. MacGillivray (Ed.), Narrative of the Voyage of H.M.S. Rattlesnake, Commanded by the Late Captain Owen Stanley during the Years 1846-50, Vol. 1 (pp. 343-402). London: Boone.

Calder, D. R. (1997). Shallow-water hydroids of bermuda: superfamily Plumularioidea. Life Sciences Contributions Royal Ontario Museum, 161, 1-85.

Cartwright, P. \& Nawrocki, A. M. (2010). Character evolution in hydrozoa (phylum Cnidaria). Integrative and Comparative Biology, 50, 456-472.

Chen, C. A., Odorico, D. M., ten Lohuis, M., Veron, J. E. \& Miller, D. J. (1995). Systematic relationships within the Anthozoa (Cnidaria: Anthozoa) using the $5^{\prime}$-end of the $28 \mathrm{~S}$ rDNA. Molecular Phylogenetics and Evolution, 4, 175-183.

Collins, A. G. (2002). Phylogeny of Medusozoa and the evolution of cnidarian life cycles. Fournal of Evolutionary Biology, 15, 418432.

Collins, A. G., Winkelmann, S., Hadrys, H. \& Schierwater, B. (2005). Phylogeny of Capitata and Corynidae (Cnidaria, Hydrozoa) in light of mitochondrial $16 \mathrm{~S}$ rDNA data. Zoologica Scripta, 34, 91-99.

Cunningham, C. W. \& Buss, L. W. (1993). Molecular evidence for multiple episodes of paedomorphosis in the family Hydractiniidae. Biochemical Systematics and Ecology, 21, 57-69.

Daly, M., Fautin, D. G. \& Cappola, V. A. (2003). Systematics of the Hexacorallia (Cnidaria: Anthozoa). Zoological fournal of the Linnean Society, 139, 419-437.

Daly, M., Brugler, M. R., Cartwright, P., Collins, A. G., Dawson, M., Fautin, D. G., France, S. C., McFadden, C. S., Opresko, D. M., Rodriguez, E., Romano, S. L. \& Stake, J. L. (2007). The phylum Cnidaria: a review of phylogenetic patterns and diversity 300 years after Linnaeus. Zootaxa, 1668, 127-182.

Darriba, D., Taboada, G. L., Doallo, R. \& Posada, D. (2012). jModelTest 2: more models, new heuristics and parallel computing. Nature, 9, 772.

Dayrat, B. (2005). Towards integrative taxonomy. Biological fournal of the Linnean Society, 85, 407-415.

Di Camillo, C. G., Bavestrello, G., Valisano, L. \& Puce, S. (2008). Spatial and temporal distribution in a tropical hydroid assemblage. Journal of the Marine Biological Association of the United Kingdom, 88, 1589.

Di Camillo, C. G., Puce, S. \& Bavestrello, G. (2009). Macrorbynchia species (Cnidaria: Hydrozoa) from the Bunaken Marine Park (North Sulawesi, Indonesia) with a description of two new species. Italian Fournal of Zoology, 76, 208-228.
Edgar, R. C. (2004). MUSCLE: a multiple sequence alignment method with reduced time and space complexity. $B M C$ Bioinformatics, 5, 113.

Erixon, P., Svennblad, B., Britton, T. \& Oxelman, B. (2003). Reliability of bayesian posterior probabilities and bootstrap frequencies in phylogenetics. Systematic Biology, 52, 665-673.

Fraser, C. M. (1938). Hydroids of the 1934 Allan Hancock Pacific Expedition. Allan Hancock Pacific Expedition, 4, 1-105.

Gittenberger, A., Reijnen, B. T. \& Hoeksema, B. W. (2011). A molecularly based phylogeny reconstruction of mushroom corals (Scleractinia: Fungiidae) with taxonomic consequences and evolutionary implications for life history traits. Contributions to Zoology, 80, 107-132.

Givnish, T. J. \& Sytsma, K. J. (1997). Molecular Evolution and Adaptive Radiation. Cambridge: Cambridge University Press.

Govindarajan, A. F., Boero, F. \& Halanych, K. M. (2006). Phylogenetic analysis with multiple markers indicates repeated loss of the adult medusa stage in Campanulariidae (Hydrozoa, Cnidaria). Molecular Phylogenetics and Evolution, $38,820-834$.

Gravier-Bonnet, N. \& Bourmaud, C. A. F. (2006a). Hydroids (Cnidaria, Hydrozoa) of coral reefs: preliminary results on community structure, species distribution and reproductive biology in Juan de Nova Island (Southwest Indian Ocean). Western Indian Ocean Fournal of Marine Science, 5, 123-132.

Gravier-Bonnet, N. \& Bourmaud, C. A. F. (2006b). Hydroids (Cnidaria, Hydrozoa) of coral reefs: preliminary results on community structure, species distribution and reproductive biology in the Ile Glorieuses (Southwest Indian Ocean) (pp. 188-196). Presented at the Proceedings of 10th International Coral Reef Symposium, Okinawa: Western Indian Ocean Marine Science Association.

Gravier-Bonnet, N. \& Bourmaud, C. A. F. (2012). Hydroids (Cnidaria, Hydrozoa) of Baa Atoll (Indian Ocean, Maldives Archipelago). Atoll Research Bulletin, 590, 85-123.

Guindon, S., Dufayard, J. F., Lefort, V., Anisimova, M., Hordijk, W. \& Gascuel, O. (2010). New algorithms and methods to estimate maximum-likelihood phylogenies: assessing the performance of PhyML 3.0. Systematic Biology, 59, 307-321.

Hibino, Y., Todd, P. A., Yang, S.-Y., Benayahu, Y. \& Reimer, J. D. (2014). Molecular and morphological evidence for conspecificity of two common Indo-Pacific species of Palythoa (Cnidaria: Anthozoa). Hydrobiologia, 733, 31-43.

Hincks, T. (1874). Notes on Norwegian Hydroida from deep water. Annals and Magazine of Natural History, 13, 125-137.

Hoeksema, B. W. \& Crowther, A. L. (2011). Masquerade, mimicry and crypsis of the polymorphic sea anemone Phyllodiscus semoni and its aggregations in South Sulawesi. Contributions to Zoology, 80, 251-268.

Hurst, G. D. D. \& Jiggins, F. M. (2005). Problems with mitochondrial DNA as a marker in population, phylogeographic and phylogenetic studies: the effects of inherited symbionts. Proceedings of the Royal Society B: Biological Sciences, 272, 15251534.

Imazu, M. A., Ale, E. \& Genzano, G. N. (2014). A comparative study of populations of Ectopleura crocea and Ectopleura ralphi (Hydrozoa, Tubulariidae) from the Southwestern Atlantic Ocean. Zootaxa, 3753, 421-439. 
Jäderholm, E. (1903). Aussereuropäische Hydroiden im schwedischen Reichsmuseum. Arkiv För Zoologi, 1, 259-312.

Johnston, G. (1838). A History of British zoophytes, Vol. I-XII. Edinburgh: Lizards.

Kayal, E., Roure, B., Philippe, H., Collins, A. G. \& Lavrov, D. V. (2013). Cnidarian phylogenetic relationships as revealed by mitogenomics. BMC Evolutionary Biology, 13, 1-1.

Kearse, M., Moir, R., Wilson, A., Stones-Havas, S., Cheung, M., Sturrock, S., Buxton, S., Cooper, A., Markowitz, S., Duran, C., Thierer, T., Ashton, B., Meintjes, P. \& Drummond, A. J. (2012). Geneious Basic: an integrated and extendable desktop software platform for the organization and analysis of sequence data. Bioinformatics, 28, 1647-1649.

Kirchenpauer, G. H. (1872). Ueber die Hydroidenfamilie Plumularidae, einzelne gruppen derselben und ihre Fruchtbehälter, I. Aglaophenia. Abhandlungen Aus Dem Gebiet Der Naturwissenschaften, Herausgegeben Von Dem Naturwissenschaftlichen Verein, 5, 1-52 pls $1-8$.

Kirchenpauer, G. H. (1876). Ueber die Hydroidenfamilie Plumularidae, einzelne gruppen derselben und ihre Fruchtbehälter, II. Plumularia und Nemertesia. Abhandlungen Aus Dem Gebiet Der Naturwissenschaften, Herausgegeben Von Dem Naturwissenschaftlichen Verein, 6, 1-59.

Kitano, Y. F., Benzoni, F., Arrigoni, R., Shirayama, Y., Wallace, C. C. \& Fukami, H. (2014). A phylogeny of the family Poritidae (Cnidaria, Scleractinia) based on molecular and morphological analyses. PLOS ONE, 9, e98406.

Lamouroux, J. V. F. (1812). Extrait d'un mémoire des polypiers coralligènes non entièrement pierreux. Nouveau Bulletin Des Sciences Par La Société Philomatique De Paris, 3, 181-188.

Lamouroux, J. V. F. (1816). Histoire des Polypiers coralligènes flexibles, vulgairement nommés Zoophytes. Caen: F. Poisson.

Leclère, L., Schuchert, P. \& Manuel, M. (2007). Phylogeny of the Plumularioidea (Hydrozoa, Leptothecata): evolution of colonial organisation and life cycle. Zoologica Scripta, 36, 371-394.

Leclère, L., Schuchert, P., Cruaud, C., Couloux, A. \& Manuel, M. (2009). Molecular phylogenetics of Thecata (Hydrozoa, Cnidaria) reveals long-term maintenance of life history traits despite high frequency of recent character changes. Systematic Biology, 58, 509-526.

Lindner, A., Cairns, S. D. \& Cunningham, C. W. (2008). From offshore to onshore: multiple origins of shallow-water corals from deep-sea ancestors. PLOS ONE, 3, e2429.

Lindner, A., Govindarajan, A. F. \& Migotto, A. E. (2011). Cryptic species, life cycles, and the phylogeny of Clytia (Cnidaria: Hydrozoa: Campanulariidae). Zootaxa, 2980, 23-36.

Linnaeus, C. (1758). Systema Naturae, 10th edn, Vol. 1. Stockholm: Laurenti salvii, Holmiae.

Mace G. M. (2004). The role of taxonomy in species conservation. Proceedings of the Royal Society B: Biological Sciences, 359, 711-719.

Marktanner-Turneretscher, G. (1890). Hydroiden des K\& K. Naturhistorischen Hofmuseums. Annalen Des K. K. Naturhistorischen Hofmuseums, 5, 195-286.

Marques, A. C. \& Collins, A. G. (2004). Cladistic analysis of Medusozoa and Cnidarian evolution. Invertebrate Biology, 123, 23-42.

Martínez, D. E., Iñiguez, A. R., Percell, K. M., Willner, J. B., Signorovitch, J. \& Campbell, R. D. (2010). Phylogeny and biogeography of Hydra (Cnidaria: Hydridae) using mitochondrial and nuclear DNA sequences. Molecular Phylogenetics and Evolution, 57, 403-410.
McFadden, C. S., Sanchez, J. A. \& France, S. C. (2010). Molecular phylogenetic insights into the evolution of Octocorallia: a review. Integrative and Comparative Biology, 50, 389-410.

Miglietta, M. P. \& Cunningham, C. W. (2012). Evolution of life cycle, colony morphology, and host specificity in the family hydractiniidae (Hydrozoa, Cnidaria). Evolution, 66, 3876-3901.

Millard N. A. H. (1975). Monograph on the hydroida of Southern Africa. Trustees of the South African museum. Annals of the South African Museum, 68, 1-513.

Miranda, L. S., Collins, A. G. \& Marques, A. C. (2010). Molecules clarify a cnidarian life cycle - the "hydrozoan" Microbydrula limopsicola is an early life stage of the staurozoan Haliclystus antarcticus. PLoS ONE, 5, e10182.

Moura, C. J., Harris, D. J., Cunha, M. R. \& Rogers, A. D. (2008). DNA barcoding reveals cryptic diversity in marine hydroids (Cnidaria, Hydrozoa) from coastal and deep-sea environments. Zoologica Scripta, 37, 93-108.

Moura, C. J., Cunha, M. R., Porteiro, F. M. \& Rogers, A. D. (2011). The use of the DNA barcode gene 16S mRNA for the clarification of taxonomic problems within the family Sertulariidae (Cnidaria, Hydrozoa). Zoologica Scripta, 40, 520-537.

Moura, C. J., Cunha, M. R., Porteiro, F. M. \& Rogers, A. D. (2012). A molecular phylogenetic appraisal of the systematics of the Aglaopheniidae (Cnidaria: Hydrozoa, Leptothecata) from the north-east Atlantic and west Mediterranean. Zoological fournal of the Linnean Society, 164, 717-727.

Nawrocki, A. M., Schuchert, P. \& Cartwright, P. (2010). Phylogenetics and evolution of Capitata (Cnidaria: Hydrozoa), and the systematics of Corynidae. Zoologica Scripta, 39, 290-304.

Nutting, C. C. (1900). American Hydroids. Part I. The Plumulariidae. Special Bulletin of the U.S. National Museum, 4, 1-285.

Nutting, C. C. (1905). Hydroids of the Hawaiian Islands collected by the steamer Albatross in 1902. Bulletin of the United States Fish Commission, 23, 931-959.

Payo, D. A., Leliaert, F., Verbruggen, H., D’hondt, S., Calumpong, H. P. \& De Clerck, O. (2013). Extensive cryptic species diversity and fine-scale endemism in the marine red alga Portieria in the Philippines. Proceedings of the Royal Society B: Biological Sciences, 280, 20122660.

Peña Cantero, A. L., Vervoort, W. \& Svoboda, A. (1996). Species of Schizotricha Allman, 1883 (Cnidaria, Hydrozoa) from recent antarctic expeditions with RV Tolarstern, with the description of a new species. Zoologische Mededelingen, 70, 411-435.

Peña Cantero, A. L., Sentandreu, V. \& Latorre, A. (2009). Phylogenetic relationships of the endemic Antarctic benthic hydroids (Cnidaria, Hydrozoa): what does the mitochondrial 16S rRNA tell us about it? Polar Biology, 33, 41-57.

Roberts, C. M., McClean, C. J., Veron, J. E. N., Hawkins, J. P., Allen, G. R., McAllister, D. E., Mittermeier, C. G., Schueler, F. W., Spalding, M., Wells, F., Vynne, C. \& Werner, T. B. (2002). Marine biodiversity hotspots and conservation priorities for tropical reefs. Science, 295, 1280-1284.

Romano, S. L. \& Palumbi, S. R. (1997). Molecular evolution of a portion of the mitochondrial $16 \mathrm{~S}$ ribosomal gene region in scleractinian corals. Fournal of Molecular Evolution, 45, 397-411.

Ronquist, F., Teslenko, M., van der Mark, P., Ayres, D. L., Darling, A., Hohna, S., Larget, B., Liu, L., Suchard, M. A. \& Huelsenbeck, J. P. (2012). MrBayes 3.2: efficient bayesian phylo- 
genetic inference and model choice across a large model space. Systematic Biology, 61, 539-542.

Ross, K. G., Gotzek, D., Ascunce, M. S. \& Shoemaker, D. D. (2010). Species delimitation: a case study in a problematic ant taxon. Systematic Biology, 59, 162-184.

Schuchert, P. (1993). Phylogenetic analysis of the Cnidaria. Fournal of Zoological Systematics and Evolutionary Research, 31, 161-173.

Schuchert, P. (2003). Hydroids (Cnidaria, Hydrozoa) of the Danish expedition to the Kei Islands. Steenstrupia, 27, 137-256.

Schuchert, P. (2014). High genetic diversity in the hydroid Plumularia setacea: a multitude of cryptic species or extensive population subdivision? Molecular Phylogenetics and Evolution, 76, 1-9.

Sinniger, F., Reimer, J. D. \& Pawlowski, J. (2008). Potential of DNA sequences to identify Zoanthids (Cnidaria: Zoantharia). Zoological Science, 25, 1253-1260.

Stechow, E. (1921). Uber Hydroiden der Deutschen Tiefsee-Expedition, nebst Bemerkungen uber einige andere Formen. Zoologischer Anzeiger - A fournal of Comparative Zoology, 53, 223-236.

The House of Lords. (2003). What on Earth? The threat to the science underpinning conservation: the government's response and the committee's commentary (No. 3rd). The stationery office limited, 1-13.

The Royal Society. (2003). Measuring Biodiversity for Conservation (pp. 1-65). London: The Royal Society.
Vervoort, W. (1967). Report on a collection of hydroida from the caribbean region, including an annotated checklist of caribbean hydroids. Zoologische Verbandelingen, 92, 1-122.

Zheng, L., He, J., Lin, Y., Cao, W. \& Zhang, W. (2014). 16S rRNA is a better choice than COI for DNA barcoding hydrozoans in the coastal waters of China. Acta Oceanologica Sinica, 33, 55-76.

\section{Supporting Information}

Additional Supporting Information may be found in the online version of this article:

Fig. S1. Molecular phylogeny of 18 tropical Aglaopheniidae species generated by PhyML from $16 \mathrm{~S}$ sequences.

Fig. S2. Molecular phylogeny of 18 tropical Aglaopheniidae species generated by PhyML from CAM sequences.

Fig. S3. Molecular phylogeny of 18 tropical Aglaopheniidae species generated by PhyML from ITS sequences.

Table S1. Number of newly sampled individuals per location.

Table S2. List of individuals per species used in this study, sampling site and GenBank accession numbers of $16 \mathrm{~S}$, calmodulin and ITS genes sequences. 